\title{
DAMPAK EKONOMI MAKRO DAN KINERJA PASAR MODAL ASIA TERHADAP PASAR MODAL INDONESIA PERIODE 2014-2018
}

\author{
Yosi Stefhani *), Noviarti *) \\ *)Dosen Tetap Program S1 Jurusan Manajemen Fakultas Ekonomi Universitas Satya Negara Indonesia \\ yosi.stefhani@yahoo.com,noviarti.arif@gmail.com
}

\begin{abstract}
Abstrak
Penelitian ini dilakukan dengan tujuan untuk mengetahui pengaruh faktor ekonomi makro dan kinerja pasar modal Asia terhadap kinerja pasar modal di Indonesia periode 2010-2018. Indikator faktor ekonomi yang digunakan adalah kurs dan tingkat suku bunga (SBI) sedangkan indikator kinerja pasar modal Asia yang dipilih adalah kinerja pasar modal Singapura (Strait Time Index atau STI) dan kinerja pasar modal Malaysia (Kuala Lumpur Stock Exchange atau KLSE). Indikator kinerja pasar modal di Indonesia yang digunakan Indeks Harga Saham Gabungan (IHSG). Teknik sampling yang digunakan adalah sampling jenuh. Metode analisis data yang digunakan adalah regresi linier berganda. Hasil penelitian menunjukan bahwa (1) secara simultan faktor ekonomi makro dan kinerja pasar modal Asia berpengaruh terhadap IHSG, (2)secara partial hanya faktor ekonomi makro yaitu kurs dan SBI yang mampu mempengaruhi IHSG sementara itu kinerja pasar modal Asia, STI dan KLSE tidak mampu mempengaruhi IHSG.
\end{abstract}

\section{Kata Kunci: Kurs, SBI, STI, KLSE, IHSG}

\section{PENDAHULUAN}

Pasar Modal mempunyai peranan yang penting dalam sistem perekonomian suatu Negara. Setidaknya ada 2 fungsi pasar modal dalam sistem perekonomian suatu Negara yaitu fungsi ekonomi dan fungsi keuangan. Terkait fungsi ekonomi maka pasar modal berperan menjadi fasilitator yang mempertemukan dua pihak yaitu masyarakat yang defisit produktif dan masyarakat yang surplus produktif. Sementara itu pasar modal memiliki fungsi keuangan karena pasar modal menjadi alternatif investasi yang memberikan potensi tingkat pengembalian bagi mereka yang berinvestasi sesuai jenis investasi yang dipilih. Selain 2 fungsi diatas pasar modal memberikan manfaat atas keberadaannya. Kinerja pasar modal bisa dijadikan sebagai salah satu leading indicator bagi tren ekonomi suatu Negara. Kinerja pasar modal bisa dilihat dari Indeks Harga Saham Gabungan (IHSG). Jika saham-saham yang diperjualbelikan di pasar modal meningkat maka IHSG juga semakin meningkat. Harga saham-saham yang meningkat berpotensi dikarenakan kinerja perusahaan - perusahaan yang menerbitkan saham mengalami peningkatan. Kinerja perusahaan yang mengalami peningkatan salah satunya diindikasikan adanya kenaikan pendapatan perusahaan. Kenaikan pendapatan mencerminkan kondisi pasar yang kondusif. Inilah kemudian yang menyebabkan mengapa kinerja pasar modal dijadikan sebagai salah satu leading indicator karena kinerja pasar modal yang baik dalam hal ini IHSG mencerminkan kondisi perekonomian yang kondusif.

Mengingat pentingnya fungsi dan manfaat pasar modal maka kinerja pasar modal harus diperhatikan. Salah satu indikator kinerja pasar modal adalah IHSG. IHSG adalah indikator yang menunjukan pergerakan harga saham secara keseluruhan. Indeks merupakan indikator tren pasar yang bisa memberikan gambaran bagaimana kondisi pasar secara umum apakah sedang aktif atau lesu. IHSG diharapkan selalu mengalami peningkatan karena dengan kondisi seperti itu diharapkan kondisi perekonomian juga meningkat. Tapi kondisi IHSG tidak selalu mengalami peningkatan, contohnya saja kondisi IHSG bulan JanuariFebruari 2019 yang terlihat fluktuatif seperti terlihat di grafik dibawah ini. 
Grafik 1

IHSG Bulan Januari-Februari 2019

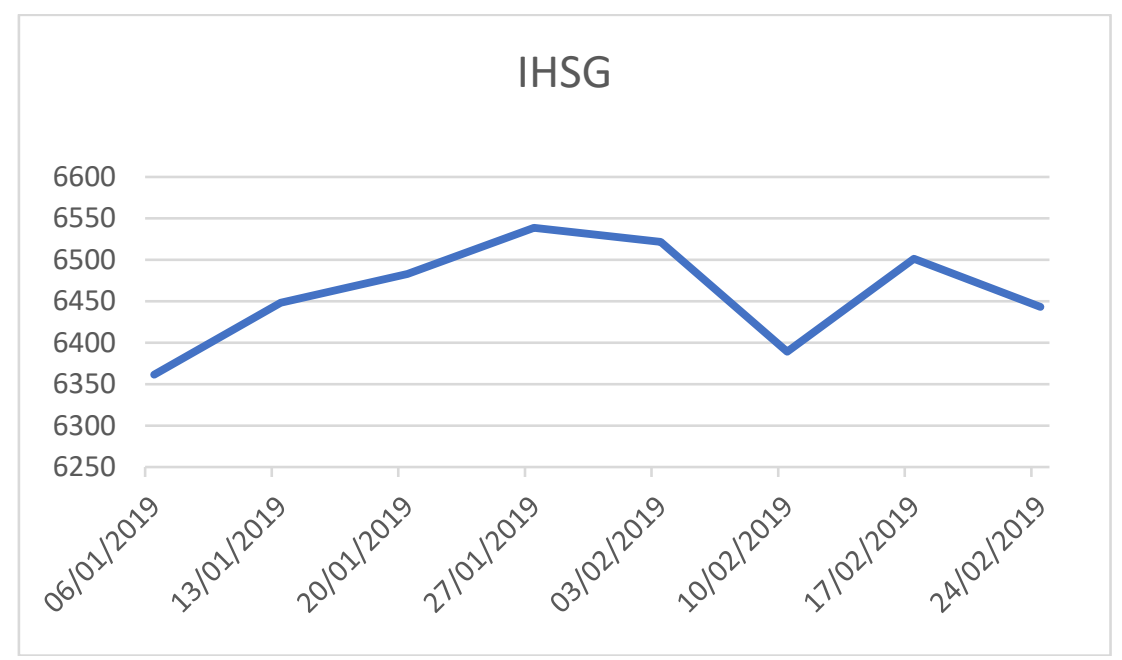

Sumber: yahoofinance.com

Dari grafik diatas terlihat bahwa data IHSG mingguan mengalami fluktuatif. Diawal Januari IHSG mengalami peningkatan di minggu pertama IHSG mencapai 6361.465 di akhir bulan atau minggu ke empat mencapai 6538,638 naik 177.1733 poin. Tetapi memasuki awal Februari IHSG mengalami penurunan dari 6521.663 menjadi 6443.348 di akhir bulan Februari turun 78.3149 poin. Kondisi ini memberikan gambaran kondisi perekonomian yang tidak stabil. Untuk bisa mendorong IHSG mengalami peningkatan atau menjaga kestabilan IHSG maka faktor-faktor yang mempengaruhi IHSG perlu diperhatikan.

Secara teoritis faktor-faktor yang mempengaruhi IHSG terdiri dari faktor internal dan faktor eksternal suatu Negara. Faktor internal yang dimaksud terkait faktor ekonomi makro diantaranya kurs dan tingkat suku bunga. Sementara itu faktor eksternal yang dimaksud terkait adanya integrasi pasar modal di dunia. Kurs dollar misalnya yang merupakan nilai tukar dollar terhadap rupiah secara teoritis dianggap mampu mempengaruhi IHSG. Jika kurs dollar naik maka perusahaan yang menggunakan mata uang dollar dalam kegiatan operasional akan mengalami peningkatan biaya operasionalnya. Jika biaya operasional meningkat maka berpotensi mengurangi laba perusahaan. Penurunan laba perusahaan kemudian akan menurunkan permintaan akan saham perusahaan tersebut. Penurunan akan permintaan saham perusahaan tersebut akan berpotensi menurunkan harga saham. Penurunan harga saham akan berpotensi menurunkan transaksi jual beli saham. Dan penurunan transaksi jual beli saham mampu menyebabkan IHSG menurun. Disisi lain investor kemudian juga akan lebih tertarik untuk berinvestasi pada valuta asing jika kurs dollar naik dibandingkan berinvestasi di pasar modal.

Indikator ekonomi makro lainya yaitu tingkat suku bunga. Tingkat suku bunga berpotensi mempengaruhi IHSG. Jika tingkat suku bunga naik maka para investor akan cenderung berinvestasi di pasar uang dibanding berinvestasi di pasar modal. Kondisi seperti ini mampu membuat IHSG menurun. Secara teoritis faktor ekonomi makro memiliki potensi mempengaruhi IHSG, tetapi ada beberapa data yang menunjukan hal berbeda. Fenomena ini contohnya saja terlihat ditabel berikut ini :

Tabel 1

Data IHSG dan Nilai Tukar Periode 2016-2017

\begin{tabular}{|c|l|c|c|l|}
\hline No. & Indikator Ekonomi Makro & 2016 & 2017 & \multicolumn{1}{|c|}{ Keterangan } \\
\hline 1. & IHSG & $5.296,711$ & $6.355,654$ & Mengalami Kenaikan \\
\hline 2. & Nilai Tukar & 13.309 & 13.381 & Mengalami Kenaikan \\
\hline
\end{tabular}

Sumber : Dari Berbagai Sumber 
Dari tabel diatas terllihat bahwa tahun 2016 ke 2017 IHSG mengalami kenaikan tetapi di periode yang sama nilai tukar juga mengalami kenaikan. Hal ini menunjukan adanya perbedaan fakta hubungan antara indikator ekonomi makro tersebut terhadap IHSG dengan hubungan secara teoritis. Fenomena ini menjadi menarik untuk di analisa lebih lanjut. Sementara itu faktor eksternal yang dianggap mampu mempengaruhi IHSG adalah adanya integrasi pasar modal di dunia. Liberalisasi pasar modal memungkinkan terjadinya integrasi pasar modal. Investor asing bisa berinvestasi di pasar modal Indonesia dan investor domestik bisa berinvestasi di pasar modal asing. Kondisi ini memunculkan beberapa dampak terkait kinerja pasar modal Indonesia. Salah satunya investor domestik memiliki alternatif tempat untuk berinvestasi selain di pasar modal Indonesia jika dianggap pasar modal asing lebih menguntungkan. Dampak lain adalah para investor domestik berpotensi untuk cenderung mengikuti investor asing dalam mengambil keputusan. Kondisi bisa terlihat dari adanya kecenderungan kesamaan perkembangan kinerja pasar modal Indonesia dengan kinerja pasar modal Negara Asia terdekat seperti Malaysia dan Singapura seperti dibawah ini.

Tabel 2

Data Kinerja Pasar Modal Indonesia, Malaysia, Singapura

\begin{tabular}{|c|c|c|c|}
\hline Tahun & $\begin{array}{c}\text { Indonesia } \\
\text { JKSE }\end{array}$ & $\begin{array}{c}\text { Malaysia } \\
\text { KLSE }\end{array}$ & $\begin{array}{c}\text { Singapura } \\
\text { STI }\end{array}$ \\
\hline \hline $\mathbf{2 0 1 6}$ & $5.296,71$ & $1.641,42$ & $2.880,76$ \\
\hline $\mathbf{2 0 1 7}$ & $6.355,65$ & $1.796,81$ & $3.402,92$ \\
\hline \hline
\end{tabular}

Sumber : yahoofinance.com

Berdasarkan tabel 2 di atas, dapat dilihat perubahan yang terjadi pada indeks harga saham Indonesia, Malaysia dan Singapura pada tahun 2017 mengalami kenaikan dari tahun sebelumnya dan di periode yang sama IHSG Indonesiapun ikut mengalami kenaikan. Fenomena ini menunjukkan bahwa konsep integrasi pasar modal berpotensi terjadi di setiap negara. Karena, pada dasarnya pergerakan pasar modal tidak hanya dipengaruhi oleh faktor internal melainkan juga faktor ekternal.

Penelitian terkait faktor ekonomi makro dan kinerja pasar modal asing yang mempengaruhi IHSG telah banyak dilakukan tetapi masih terdapat perbedaan hasil penelitian Penelitian yang dilakukan Luh Gede (2017) hasil penelitiannya menunjukan bahwa tingkat suku bunga dan Indeks Pasar Modal Singapura (Strait Time Index) berpengaruh terhadap IHSG tetapi kurs tidak mampu mempengaruhi IHSG. Sementara itu Ni Made (2018) melakukan penelitian yang menunjukan hasil penelitian bahwa kurs dan Indeks Pasar Modal Malaysia (Kuala Lumpur Stock Exchange) mampu mempengaruhi IHSG, sementara Indeks Pasar Modal Singapura (Strait Time Index) tidak mampu mempengaruhi IHSG . Hasil penelitian yang berbeda juga ditunjukan dari penelitian yang dilakukan R.Sarifoh (2018) yaitu kurs mampu mempengaruhi IHSG, sedangkan Indeks Pasar Modal Malaysia (Kuala Lumpur Stock Exchange) tidak mampu mempengaruhi IHSG. Dan terakhir penelitian yang dilakukan Diongsia (2015) menunjukan bahwa tingkat suku bunga tidak mampu mempengaruhi IHSG.

Berdasarkan fenomena yang ada dan masih adanya perbedaan hasil penelitian sebelumnya maka peneliti tertarik untuk melakukan penelitian terkait dampak ekonomi makro dan kinerja pasar modal Asia terhadap pasar modal Indonesia.

\section{KERANGKA PEMIKIRAN TEORITIS}

\section{Kinerja Pasar Modal Indonesia}

Kinerja pasar modal bisa dilihat dari IHSG. Sementara itu indeks harga saham gabungan adalah indikator yang menunjukkan pergerakan harga saham. Indeks berfungsi sebagai indikator tren pasar, artinya pergerakan indeks menggambarkan kondisi pasar pada 
suatu saat apakah pasar sedang aktif atau lesu. Dalam hal ini pasar modal Indonesia adalah Bursa Efek Indonesia (BEI). Jadi IHSG adalah indikator pergerakan harga semua saham yang tercatat di Bursa Efek Indonesia baik saham biasa maupun saham preferen. Indeks inilah yang paling banyak digunakan dan dipakai sebagai acuan tentang perkembangan kegiatan di pasar modal. IHSG bisa dipakai untuk menilai situasi pasar secara umum atau mengukur apakah harga saham mengalami kenaikan atau penurunan karena IHSG melibatkan seluruh harga saham yang tercatat di Bursa Efek Indonesia. Indeks Harga Saham Gabungan pertama kali diperkenalkan pada tanggal 1 April 1983 sebagai indikator pergerakan harga semua saham yang tercatat di Bursa Efek Jakarta yang sekarang disebut Bursa Efek Indonesia baik saham biasa maupun saham preferen.

Cara untuk menghitung Indeks Harga Saham Gabungan adalah dengan menggunakan metode rat-rata tertimbang nilai pasar (market value weighted average index) sebagai berikut

Dimana :

$$
\mathrm{IHSG}=\frac{\text { Nilai Pasar }}{\text { Nilai Dasar }} x 100
$$

Nilai Pasar adalah kumulatif jumlah saham hari ini dikali harga pasar hari ini atau disebut dengan kapitalisasi pasar.

Nilai Dasar adalah nilai yang dihitung berdasarkan harga perdana dari masing-masing saham atau berdasarkan harga yang telah dikoreksi, jika perusahaan telah melakukan kegiatan yang menyebabkan jumlah saham yang tercatat di bursa berubah. Penyesuaian dilakukan agar indeks akan benar-benar mencerminkan pergerakan harga saham.

\section{Faktor-Faktor Yang Mempengaruhi Kinerja Pasar Modal Indoensia}

Penelitian ini menggunakan dua pendekatan teori, yaitu Signaling theory dan Contagion Effect theory.

1. Signaling theory menjelaskan alasan perusahaan menyajikan informasi untuk pasar modal. Signaling theory menunjukkan adanya asimetri informasi antara manajemen perusahaan dan pihak-pihak yang berkepentingan. Suatu informasi yang diumumkan ke khalayak umum akan menjadi sebuah sinyal bagi investor dalam pengambilan keputusannya. Pasar nantinya akan bereaksi atas informasi yang tersedia, baik itu good news maupun bad news.

2. Contagion effect theory merupakan suatu efek penularan yang terjadi secara beruntun diantara negara-negara yang saling berhubungan. Suatu krisis dapat menular pada negara lain bilamana negara-negara tersebut memiliki kondisi perekonomian yang sama. Contagion effect terjadi karena adanya perilaku kolektif dari investor. Hal ini bisa terjadi dikarenakan para investor berbagi informasi yang sama dimana informasi ini dapat memicu terjadinya perubahan ekspektasi dalam pasar modal.

Sementara itu beberapa faktor yang mempengaruhi pergerakan Indeks Harga Saham yaitu faktor internal dan faktor eksternal.

1. Faktor Internal. Faktor internal yang terdiri dari faktor ekonomi mikro dan faktor ekonomi makro. Faktor ekonomi mikro diantaranya:

a. Kinerja para emiten di pasar modal. Kinerja para emiten di pasar modal mampu mempengaruhi perdagangan di pasar modal. Jika pada umumnya kinerja para emiten baik maka akan berpotensi menyebabkan pedagangan yang aktif di pasar modal dan ini pada akhirnya akan mempengaruhi IHSG.

b. Coorporate action yang dilakukan emiten di pasar modal seperti akusisi, merger, stock split dan yang lainnya. Corporate action berpotensi mampu mempengaruhi perdagangan di pasar modal sehingga dapat mempengaruhi IHSG.

Sementara itu faktor ekonomi makro diantaranya :

a. Kurs menunjukkan harga atau nilai mata uang suatu negara dinyatakan dalam nilai mata uang negara lain. Jika kurs dollar naik maka perusahaan yang menggunakan mata uang dollar dalam kegiatan operasional akan mengalami 
peningkatan biaya operasionalnya. Jika biaya operasional meningkat maka berpotensi mengurangi laba perusahaan. Penurunan laba perusahaan kemudian akan menurunkan permintaan akan saham perusahaan tersebut. Penurunan akan permintaan saham perusahaan tersebut akan berpotensi menurunkan harga saham. Penurunan harga saham dan penurunan transaksi jual beli saham mampu menyebabkan IHSG menurun. Disisi lain investor kemudian juga akan lebih tertarik untuk berinvestasi pada valuta asing jika kurs dollar naik dibandingkan berinvestasi di pasar modal.

b. Inflasi sebagai suatu proses meningkatnya harga-harga secara umum dan terusmenerus berkaitan dengan mekanisme pasar yang dapat disebabkan oleh berbagai faktor, antara lain, konsumsi masyarakat yang meningkat, berlebihnya likuiditas di pasar yang memicu konsumsi atau bahkan spekulasi, sampai termasuk juga akibat adanya ketidaklancaran distribusi barang. Jika inflasi naik maka biaya operasional perusahaan meningkat maka hal ini yang menyebabkan penurunan laba perusahaan. Penurunan laba perusahaan kemudian akan membuat permintaan saham menurun sehingga terjadi penurunan transaksi jual beli saham yang mampu menyebabkan IHSG ikut turun.

c. Tingkat Suku bunga adalah nilai, tingkat, atau keuntungan yang diberikan kepada investor dari penggunaan dana investasi atas dasar perhitungan nilai ekonomis dalam periode waktu tertentu. Tingkat suku bunga Bank digunakan untuk mengontrol perekonomian suatu negara. Jika tingkat suku bunga naik maka para investor akan cenderung berinvestasi di pasar uang dibanding berinvestasi di pasar modal. Kondisi seperti ini mampu membuat IHSG menurun.

2. Faktor eksternal yang mampu mempengaruhi IHSG diantaranya adanya integrasi pasar modal di dunia. Efek hubungan ekonomi Indonesia dengan negara lainnya menyebabkan pasar modal Indonesia terintegrasi. Di era globalisasi ekonomi seperti sekarang ini menyebabkan semakin terintegrasinya pasar modal suatu negara dengan pasar modal global. Umumnya indeks bursa yang memiliki pengaruh yang kuat terhadap kinerja indeks bursa efek lainnya adalah indeks bursa efek yang tergolong maju. Pasar modal yang terintegrasi menunjukkan pergerakan bersama indeks pasar saham yang stabil dalam jangka panjang, tetapi dalam jangka pendek kemungkinan harga saham antar pasar modal dapat berbeda. Konsep ini juga dapat menjelaskan kemungkinan investor memperoleh keuntungan diversifikasi portofolio internasional hanya dalam jangka pendek jika derajat pergerakan bersama pasar modal dalam jangka panjang tinggi atau pasar modal semakin terintegrasi. Dampak dari integrasi pasar modal juga munculnya strategi follower. Strategi follower yang diterapkan investor domestik dengan merujuk pada perilaku investor (Investor Behavior) asing dalam menentukan keputusan investasi dan melakukan transaksi untuk menjual atau membeli saham di pasar modal. Sehingga perilaku investor asing dibursa sahamnya masing-masing dijadikan acuan oleh para investor domestik dapat mempengaruhi pergerakan IHSG.

\section{Penelitian Terdahulu Yang Relevan}

Berbagai penelitian terdahulu yang relevan terkait penelitian ini telah banyak dilakukan tetapi hasil penelitian-penelitian tersebut masih menunjukan hasil yang berbeda. Berikut perbedaan hasil penelitian sebelumnya.

Tabel 3

Research Gap

\begin{tabular}{|c|l|l|l|}
\hline No. & Variabel & \multicolumn{1}{|c|}{ Peneliti/Tahun } & \multicolumn{1}{c|}{ Hasil Penelitian } \\
\hline 1 & Kurs & Luh Gede Sri Artini dkk (2017 & Kurs Tidak Berpengaruh Terhadap IHSG \\
\hline & & $\begin{array}{l}\text { Ni Made Sania Candradewi dan } \\
\text { Gerianta Wirawan Yasa (2018) }\end{array}$ & Kurs Berpengaruh Terhadap IHSG \\
\hline & & Dionysia Kowanda dkk (2015) & Kurs Berpengaruh Terhadap IHSG \\
\hline
\end{tabular}




\begin{tabular}{|c|l|l|l|}
\hline 2 & SBI & Dionysia Kowanda dkk (2015) & SBI Tidak Berpengaruh Terhadap IHSG \\
\hline & & Luh Gede Sri Artini dkk (2017 & SBI Berpengaruh Terhadap IHSG \\
\hline & & $\begin{array}{l}\text { Ni Made Sania Candradewi dan } \\
\text { Gerianta Wirawan Yasa (2018) }\end{array}$ & SBI Berpengaruh Terhadap IHSG \\
\hline 3 & STI & $\begin{array}{l}\text { Ni Made Sania Candradewi dan } \\
\text { Gerianta Wirawan Yasa (2018) }\end{array}$ & STI Tidak Berpengaruh Terhadap IHSG \\
\hline 4 & & Luh Gede Sri Artini dkk (2017 & STI Berpengaruh Terhadap IHSG \\
\hline & & $\begin{array}{l}\text { R Safiroh Febrina dkk (2018). } \\
\text { Gerianta Wania Candradewi dan }\end{array}$ & KLSE Tidak Berpengaruh Terhadap IHSG \\
\hline
\end{tabular}

Sumber : Dari Berbagai Jurnal Publikasi Ilmiah

Sementara itu perbedaan penelitian ini dengan penelitian yang sebelumnya terletak pada indikator-indikator variabel penelitian yang digunakan dan lamanya periode penelitian. Indikator variabel ekonomi makro yang digunakan dalam penelitian ini adalah kurs dan tingkat suku bunga sementara di penelitian sebelumnya hanya mengggunakan variabel indikator ekonomi makro lainnya seperti inflasi, indeks produksi industri, harga minyak dunia dan pertumbuhan Produk Domestik Bruto. Sementara itu kinerja pasar modal lain yang digunakan hanya menggunakan kinerja pasar modal Asia. Kinerja pasar modal Asia yang digunakan dalam penelitian ini adalah kinerja pasar modal Singapura dan Malaysia. Sementara iu penelitian lainnya ada yang menggunakan kinerja pasar modal Asia lainnya seperti Philipina, Thailand, Jepang dan Hongkong. Perbedaan lainnya antara penelitian ini dengan penelitiannnya sebelumnya adalah periode penelitian yang lebih panjang yaitu 9 tahun dari 2010 sampai dengan 2018. Sementara itu penelitian sebelumnya periode penelitian paling lama 8 tahun dan periode paling sedikit 5 tahun.

\section{Kerangka Pemikiran Penelitian}

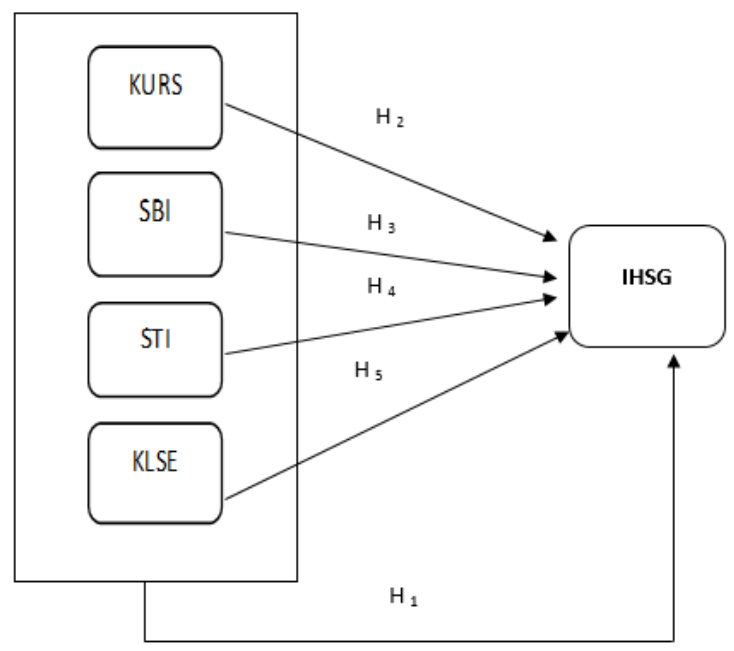

Gambar 1

Kerangka Pemikiran Penelitian

Berdasarkan kerangka pemikiran penelitian diatas disusunlah hipotesis penelitian. Hipotesis memberikan keterangan sementara mengenai fenomena yang diteliti, dalam hal ini adalah hubungan antara variabel bebas dan variabel terikat. Maka dapat dirumuskan hipotesisnya sebagai berikut:

a. Hipotesis uji secara simultan

Pengujian ini merupakan pengujian yang dilakukan untuk mengetahui apakah variabel bebas secara simultan mempunyai pengaruh yang signifikan terhadap variabel terikat. 
$\mathrm{H}_{01}$ : Tidak terdapat pengaruh kurs, SBI, STI dan KLSE secara simultan terhadap IHSG.

$\mathrm{H}_{\mathrm{a} 1}$ : Terdapat pengaruh kurs, SBI, STI dan KLSE secara simultan terhadap IHSG.

b. Hipotesis uji secara parsial

Pengujian ini dilakukan untuk menguji apakah setiap variabel bebas mempunyai pengaruh yang signifikan terhadap variabel terikat.

$\mathrm{H}_{02}$ : Tidak terdapat pengaruh kurs terhadap IHSG

$\mathrm{Ha}_{2}$ : Terdapat pengaruh kurs terhadap IHSG .

$\mathrm{H}_{03}$ : Tidak terdapat pengaruh SBI bunga terhadap IHSG.

$\mathrm{Ha}_{3}$ : Terdapat pengaruh SBI bunga terhadap IHSG.

$\mathrm{H}_{04}$ : Tidak terdapat pengaruh STI terhadap IHSG.

$\mathrm{Ha}_{4}$ : Terdapat pengaruh STI terhadap IHSG.

$\mathrm{H}_{05}$ : Tidak terdapat pengaruh KLSE terhadap IHSG.

$\mathrm{Ha}_{5}$ : Terdapat pengaruh KLSE terhadap IHSG.

\section{METODE}

\section{Populasi dan Sampel}

Populasi dalam penelitian ini adalah seluruh data penutupan tiap akhir bulan, nilai tukar Rupiah atas Dollar AS, tingkat suku bunga SBI dan indeks harga saham Singapura dan Malaysia pada tahun 2010-2018. Metode penentuan sampel yang digunakan dalam penelitian ini adalah sampling jenuh, yaitu teknik pengumpulan sampel dengan metode sensus. Pada metode sampling jenuh seluruh populasi merupakan sampel, maka dari itu jumlah sampel yang digunakan sama dengan jumlah populasinya.

\section{Desain Penelitian}

Dalam penelitian ini desain penelitian yang digunakan yaitu Penelitian Kausal, yaitu penelitian yang bertujuan untuk mengetahui pengaruh antara satu atau lebih variabel independen terhadap variabel dependen.

\section{Jenis dan Sumber Data}

Jenis data dalam penelitian ini adalah data sekunder. Data sekunder adalah data yang telah diolah sebelumnya. Sumber data dari data nilai tukar Rupiah atas Dollar AS, tingkat suku bunga SBI dan indeks harga saham Singapura dan Malaysia pada tahun 2010-2018 yang tersedia di finance.yahoo.com, id.investing.com, dan www.bi.go.id.

\section{Definisi Operasional Variabel dan Skala Pengukurannya}

Pada penelitian ini terdapat dua jenis variabel yang akan diteliti, yaitu:

1. Variabel Terikat (Dependent Variable) yaitu variabel yang diduga sebagai akibat atau variabel yang dipengaruhi oleh variabel yang mendahuluinya, yakni variabel bebas. Variabel terikat dalam penelitian ini adalah IHSG.

2. Variabel Bebas (Independent Variable) yaitu variabel penduga dalam penelitian yang mempengaruhi variabel terikat, baik secara positif atau negatif . Variabel bebas dalam penelitian ini adalah:
a. Kurs
b. Tingkat Suku Bunga
c. Indeks STI
d. Indeks KLSE

Tabel 4

Definisi dan Operasional Variabel 


\begin{tabular}{|c|c|c|c|c|}
\hline No. & Variabel Penelitian & Definisi Operasional & Parameter & $\begin{array}{c}\text { Skala } \\
\text { Pengukuran }\end{array}$ \\
\hline 1 & IHSG & $\begin{array}{l}\text { Pergerakan harga saham di BEI, } \\
\text { Indeks ini mencakup pergerakan } \\
\text { harga seluruh saham biasa dan } \\
\text { saham preferen yang tercatat di BEI. }\end{array}$ & $\begin{array}{c}\mathrm{IHSG}= \\
\text { Harga Pasar } \\
\text { Harga Dasar }\end{array}$ & Ratio \\
\hline 2 & Kurs & $\begin{array}{l}\text { Harga sebuah mata uang dari sutu } \\
\text { negara yang diukur atau dinyatakan } \\
\text { dalam mata uang lainnya }\end{array}$ & Kurs USD/Rp & Ratio \\
\hline 3 & Tingkat Suku Bunga & $\begin{array}{l}\text { nilai, tingkat, harga atau keuntungan } \\
\text { yang diberikan kepada investor dari } \\
\text { penggunaan dana investasi atas } \\
\text { dasar perhitungan nilai ekonomis } \\
\text { dalam periode waktu tertentu. }\end{array}$ & SBI & Ratio \\
\hline 4 & STI & $\begin{array}{l}\text { Indeks pasar saham berdasarkan } \\
\text { kapitalisasi Bursa Efek di Singapura }\end{array}$ & $\begin{array}{c}\text { STI }= \\
\text { Harga Pasar } \\
\text { Harga Dasar }\end{array}$ & Ratio \\
\hline 5 & KLSE & $\begin{array}{l}\text { Indeks pasar saham berdasarkan } \\
\text { kapitalisasi Bursa Efek di Singapura }\end{array}$ & $\begin{array}{c}\text { KLSE }= \\
\text { Harga Pasar } \\
\text { Harga Dasar }\end{array}$ & Ratio \\
\hline
\end{tabular}

Sumber : Dari Berbagai Sumber

\section{Metode Analisis data}

Analisa Regresi Linier Berganda

Model regresi linier dikatakan sebagai model yang baik hanya jika model tersebut memenuhi asumsi-asumsi klasik yaitu data residual terdistribusi normal, tidak adanya multikolinieritas, autokorelasi dan heterokedastisitas.

\section{a. Uji Asumsi Klasik}

\section{- Uji Normalitas Residual}

Uji ini bertujuan untuk menguji residual data yang digunakan telah terdistribusi normal. Model regresi yang baik adalah yang memiliki residual data terdistribusi normal. Menguji normalitas data, dapat dilihat pada grafik probability plot. Data dapat dikatakan normal bila data atau titik titik tersebar disekitar garis diagonal dan penyebarannya mengikuti garis diagonalnya.

- Uji Multikolinieritas

Uji multikolonieritas bertujuan untuk menguji apakah model regresi ditemukan adanya korelasi antar variabel bebas. Model regresi yang baik seharusnya tidak terjadi korelasi diantara variabel bebas. Untuk mendeteksi ada atau tidaknya gejala multikolinieritas dalam suatu model regresi dapat diketahui dari Variance Inflation Factor (VIF) apabila nilai VIF kurang dari 10 dan Tolerance lebih dari 0,1 maka dinyatakan tidak terjadi multikolinieritas.

- Uji Autokorelasi

Uji ini bertujuan untuk menguji apakah dalam model regresi linier ada korelasi antara kesalahan pengganggu pada periode $t$ dengan kesalahan pengganggu pada periode $t-1$ (sebelumnya). Pengujian ada tidaknya autokorelasi dalam persamaan ini digunakan uji Durbin Watson (DW - test). Model regresi yang baik adalah model yang tidak mengandung autokorelasi. Jika nilai uji statistik Durbin-Watson lebih kecil dari satu atau lebih besar dari tiga , maka model regresi mengandung autokorelasi.

- Uji Heteroskedastisitas

Uji heteroskedastisitas bertujuan untuk menguji apakah dalam sebuah model regresi terjadi ketidaksamaan varians dari suatu pengamatan ke pengamatan yang lain. Model regrasi yang baik adalah seharusnya tidak terjadi heteroskedastisitas. Uji heteroskedastisitas bisa dengan melihat pola titik-titik pada grafik regresi. Jika tidak ada pola yang jelas, seperti titik-titik menyebar di atas dan dibawah angka 0 pada sumbu Y, maka tidak terjadi heteroskedastisitas,

\section{b. Uji Hipotesis}


Metode analisis regresi linear berganda merupakan suatu bentuk hubungan linear antara dua atau lebih variabel independen dengan variabel dependennya. Maka pengujian hipotesis untuk bisa menjawab permasalahan dalam penelitian ini dilakukan uji $\mathrm{F}$ dan uji t.

\section{Uji F}

Uji ini merupakan pengujian untuk pengaruh dari variabel-variabel independen secara simultan terhadap variabel dependen. Dalam pengujian ini sebelumnya dirumuskan hipotesisnya.

Ho : Variabel-Variabel Independen secara simultan tidak berpengaruh terhadap variabel dependen

Ha $\quad$ : Variabel- variabel Independen secara simultan berpengaruh terhadap variabel dependen

Kriteria pengujian untuk uji F sebagai berikut :

Jika $F$ tabel $\leq \mathrm{F}$ hitung maka Ho diterima

Jika $\mathrm{F}$ tabel $>\mathrm{F}$ Hitung maka Ho ditolak

Berdasarkan signifikansi:

Jika Signifikansi $>0,05$ maka Ho diterima

Jika Signifikansi $<0,05$ maka Ho ditolak

2. Uji t

Digunakan untuk membuktikan pengaruh variabel independen terhadap variabel dependen secara individu atau parsial. Dalam pengujian ini sebelumnya dirumuskan hipotesisnya.

Ho $\quad$ : Variabel Independen tidak berpengaruh terhadap variabel dependen

$\mathrm{Ha} \quad$ : Variabel Independen berpengaruh terhadap variabel dependen

Kriteria pengujian untuk uji t sebagai berikut :

Jika $\mathrm{t}$ tabel $\leq \mathrm{t}$ hitung $\leq \mathrm{t}$ tabel maka Ho diterima

Jika $\mathrm{t}$ tabel $<\mathrm{t}$ hitung $\leq$ atau $\mathrm{t}$ hitung $>\mathrm{t}$ tabel maka Ho ditolak

Berdasarkan signifikansi:

Jika Signifikansi $>0,05$ maka Ho diterima

Jika Signifikansi $<0,05$ maka Ho ditolak

Model Regresi Berganda dalam penelitian ini adalah sebagai berikut:

$$
\mathrm{Y}=\mathrm{a}+\mathrm{b} 1 \mathrm{x} 1+\mathrm{b} 2 \times 2+\mathrm{b} 3 \times 3+\mathrm{b} 4 \mathrm{x} 4+\mathrm{b} 5 \times 5+e
$$

Keterangan:

$\mathrm{Y} \quad=\quad \mathrm{IHSG}$

$\mathrm{a}=$ Konstanta

b1-b5 $=\quad$ Koefisien regresi variabel independen

$\mathrm{x} 1=$ Kurs

$\mathrm{x} 2=$ Tingkat Suku Bunga

$\mathrm{x} 3=\mathrm{STI}$

$\mathrm{x} 4=\mathrm{KLSE}$

$\mathrm{e} \quad=\quad$ error term

\section{PEMBAHASAN}

Pengujian regresi linier berganda tidak hanya meliputi pengujian hipotesis secara parsial dan simultan tapi sebelumnya juga dilakukan analisa uji asumsi klasik. Berikut hasil pengujian analisa asumsi klasik.

1. Uji Normalitas Residual

Berdasarkan pengujian normalitas residual terlihat bahwa data menyebar mengikuti fungsi distribusi normal yaitu menyebar seiring garis $\mathrm{z}$ diagonal, sehingga bisa disimpulkan residual terdistribusi normal. 


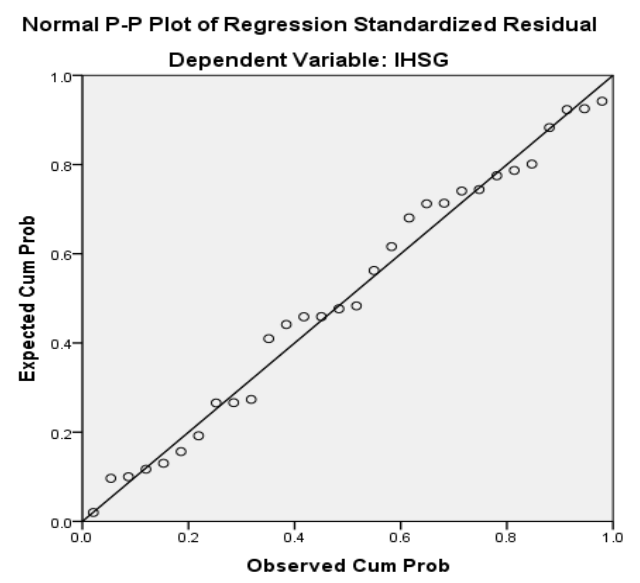

Sumber : Output SPSS

Gambar 2

Hasil Uji Normalitas Residual

2. Uji Multikolinieritas

Tabel 5

Hasil Uji Multikolinieritas

\begin{tabular}{|ll|r|c|}
\hline \multirow{2}{*}{ Model } & \multicolumn{2}{|c|}{ Collinearity Statistics } \\
\cline { 3 - 4 } & & Tolerance & \multicolumn{1}{c|}{ VIF } \\
\hline 1 & (Constant) & & \\
& KURS & .742 & 1.348 \\
& SBI & .787 & 1.271 \\
& STI & .439 & 2.278 \\
& KLSE & .398 & 2.512 \\
\hline
\end{tabular}

Sumber: Output SPSS

Berdasarkan tabel diatas terlihat nilai Tolerance lebih dari 0,1 dan nilai VIF $<10$, maka ini mengindikasikan tidak terjadinya Multikolinieritas.

3. Uji Autokorelasi

Tabel 6

Hasil Uji Autokorelasi

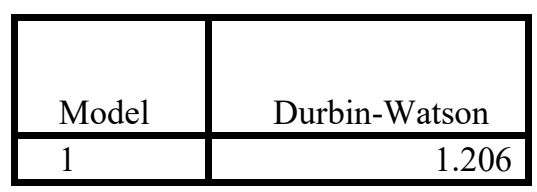

Sumber : Output SPSS

Berdasarkan tabel diatas terlihat bahwa nilai durbin Watson 1,206 artinya lebih dari 1 kurang dari 3 atau berada di range antara 1 dan 3 sehingga megindikasikan nilai residu tidak berkorelasi.

4. Uji Heterokedastisitas 


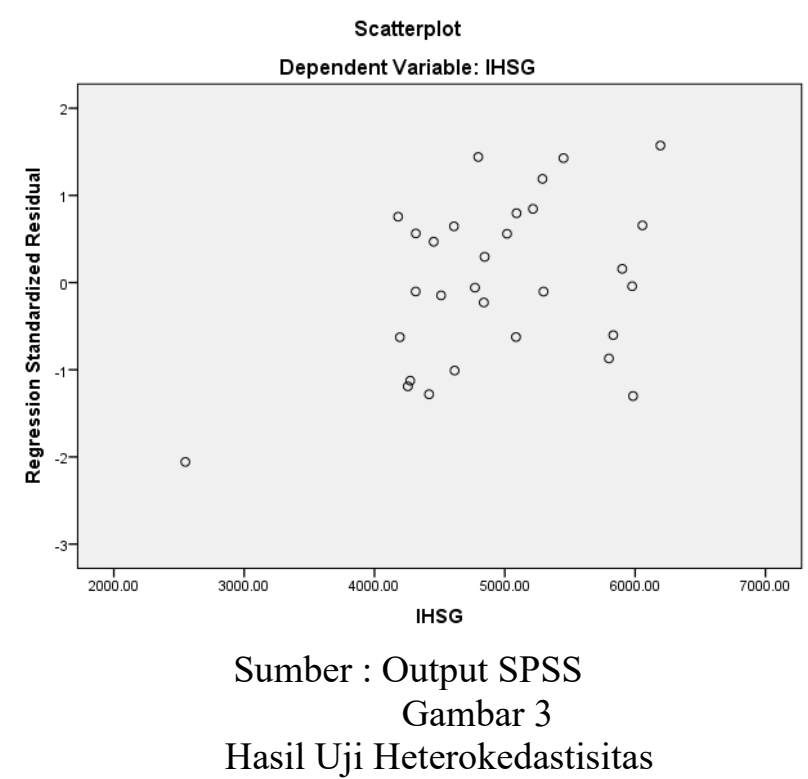

Berdasar grafik scatterplot diatas terlihat bahwa tidak ada pola yang jelas, serta titiktitik menyebar maka mengindikasikan tidak terjadi heterokedastisitas.

Setelah pengujian asumsi klasik maka dilakukan pengujian hipotesis secara simultan dan parsial. Berikut ini pengujian hipotesis secara simultan (uji F) dan secara parsial (uji t).

1. Uji $\mathbf{F}$

Berdasarkan tabel diatas maka nilai signifikansi 0,000 atau $<0.05$ ini berarti $\mathrm{H}_{0}$ di tolak dan Ha diterima sehingga bisa disimpulkan terdapat pengaruh kurs, SBI, STI dan KLSE secara simultan terhadap IHSG.

Tabel 7

\section{Hasil Uji F}

Anova

\begin{tabular}{|ll|r|r|r|r|c|}
\hline \multicolumn{2}{|l|}{ Model } & \multicolumn{1}{|c|}{$\begin{array}{c}\text { Sum of } \\
\text { Squares }\end{array}$} & df & Mean Square & F & Sig. \\
\hline 1 & Regression & 14975304.265 & 4 & 3743826.066 & 35.836 & $.000^{\mathrm{b}}$ \\
& Residual & 2611803.202 & 25 & 104472.128 & & \\
& Total & 17587107.467 & 29 & & & \\
\hline
\end{tabular}

a. Dependent Variable: IHSG

b. Predictors: (Constant), KLSE, SBI, KURS, STI

2. Uji t

Sumber : Output SPSS

Tabel 8

Hasil Uji t

\begin{tabular}{|c|c|c|c|c|c|}
\hline \multirow[b]{2}{*}{ Model } & \multicolumn{2}{|c|}{$\begin{array}{c}\text { Unstandardized } \\
\text { Coefficients }\end{array}$} & \multirow{2}{*}{$\begin{array}{c}\text { Standardized } \\
\text { Coefficients } \\
\text { Beta }\end{array}$} & \multirow[b]{2}{*}{$\mathrm{t}$} & \multirow[b]{2}{*}{ Sig. } \\
\hline & B & Std. Error & & & \\
\hline $1 \quad$ (Constant) & 1548.655 & 1062.685 & & 1.457 & .157 \\
\hline KURS & .294 & .038 & .701 & 7.831 & .000 \\
\hline SBI & -224.933 & 66.704 & -.293 & -3.372 & .002 \\
\hline STI & .743 & .375 & .231 & 1.983 & .058 \\
\hline KLSE & 1.157 & .807 & .175 & 1.432 & .164 \\
\hline
\end{tabular}




\section{Sumber : Output SPSS}

Berdasarkan tabel diatas maka dapat dapat disimpulkan beberapa hal :

a. Nilai signifikasi untuk variabel $\mathrm{X} 1$ yaitu kurs terlihat sebesar 0,000 atau $<0,05$ ini berarti $\mathrm{H}_{0}$ di tolak dan $\mathrm{Ha}$ diterima sehingga bisa disimpulkan bahwa kurs berpengaruh terhadap IHSG

b. Nilai signifikasi untuk variabel $\mathrm{X} 2$ yaitu SBI terlihat sebesar 0,002 atau $<0,05$ ini berarti $\mathrm{H}_{0}$ di tolak dan Ha diterima sehingga bisa disimpulkan bahwa SBI berpengaruh terhadap IHSG

c. Nilai signifikasi untuk variabel X3 yaitu STI terlihat sebesar 0,058 atau $>0,05$ ini berarti $\mathrm{H}_{0}$ diterima dan Ha ditolak sehingga bisa disimpulkan bahwa STI tidak berpengaruh terhadap IHSG.

d. Nilai signifikasi untuk variabel X4 yaitu KLSE terlihat sebesar 0,164 atau >0,05 ini berarti $\mathrm{H}_{0}$ diterima dan Ha ditolak sehingga bisa disimpulkan bahwa KLSE tidak berpengaruh terhadap IHSG.

\section{Uji R Square}

Tabel 9

Hasil Uji R Square

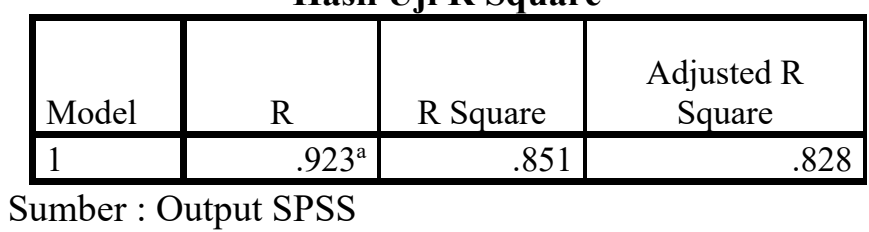

Berdasarkan tabel diatas nilai adjusted $\mathrm{R}$ square sebesar $82,8 \%$. Ini menunjukan bahwavkontribusi pengaruh variabel-variabel independen dalam hal ini kurs, SBI, STI dan KLSE dalam penelitian ini terhadap variabel dependen, IHSG sebesar 82,8\%. Sementara itu $17,2 \%$ dipengaruhi oleh vaiabel lain. Asumsi argumentasi lain variabel lai yang dimaksud diantara inflasi, kinerja emiten dalam pasar modal itu sendiri, corporate action dan lain-lain.

\section{Pembahasan Teoritis dengan Hasil Penelitian}

Secara teoritis variabel kurs, SBI, STI dan KLSE mempunyai pengaruh terhadap IHSG. Kurs menunjukkan harga atau nilai mata uang suatu negara dinyatakan dalam nilai mata uang negara lain. Jika kurs dollar naik maka perusahaan yang menggunakan mata uang dollar dalam kegiatan operasional akan mengalami peningkatan biaya operasionalnya. Jika biaya operasional meningkat maka berpotensi mengurangi laba perusahaan. Penurunan laba perusahaan kemudian akan menurunkan permintaan akan saham perusahaan tersebut. Penurunan akan permintaan saham perusahaan tersebut akan berpotensi menurunkan harga saham. Penurunan harga saham berpotensi menyebabkan investor mengurangi transaksinya. Dan penurunan transaksi jual beli saham mampu menyebabkan IHSG menurun. Disisi lain investor kemudian juga akan lebih tertarik untuk berinvestasi pada valuta asing jika kurs dollar naik dibandingkan berinvestasi di pasar modal. Hasil penelitian menunjukan bahwa kurs pengaruh terhadap IHSG dan hasil penelitian ini sesuai dengan teori.

Tingkat suku bunga Bank digunakan sebagai salah satu indikator perekonomian suatu negara. Jika tingkat suku bunga naik maka para investor akan cenderung berinvestasi di pasar uang dibanding berinvestasi di pasar modal. Kondisi seperti ini mampu membuat IHSG menurun. Hasil penelitian menunjukan bahwa SBI berpengaruh terhadap IHSG maka hasil penelitian sesuai dengan teori.

Efek hubungan ekonomi Indonesia dengan negara lainnya menyebabkan pasar modal Indonesia terintegrasi. Di era globalisasi ekonomi seperti sekarang ini menyebabkan semakin 
terintegrasinya pasar modal suatu negara dengan pasar modal global. Umumnya indeks bursa yang memiliki pengaruh yang kuat terhadap kinerja indeks bursa efek lainnya adalah indeks bursa efek yang tergolong maju. Pasar modal yang terintegrasi menunjukkan pergerakan bersama indeks pasar saham yang stabil dalam jangka panjang, tetapi dalam jangka pendek kemungkinan harga saham antar pasar modal dapat berbeda dan masing-masingnya (shortrun divergence). Dampak dari integrasi pasar modal juga munculnya strategi follower. Strategi follower yang diterapkan investor domestik dengan merujuk pada perilaku investor (Investor Behavior) asing dalam menentukan keputusan investasi dan melakukan transaksi untuk menjual atau membeli saham di pasar modal. Sehingga perilaku investor asing dibursa sahamnya masing-masing dijadikan acuan oleh para investor domestik dapat mempengaruhi pergerakan IHSG. Hasil penelitian menunjukan bahwa baik STI dan KLSE tidak berpengaruh terhadap IHSG, menunjukan hasil penelitian tidak sesuai dengan teori. Hal ini bisa saja terjadi dikarenakan investor domestik lebih mempertimbangkan kondisi perekonomian dalam negeri daripada menggunakan strategy follower dalam membuat keputusan investasi di pasar modal. Perbedaan kondisi perekonomian antara Indonesia, Singapura dan Malaysia selama periode penelitian bisa menyebabkan mengapa strategy follower tidak dipertimbangkan. Walaupun begitu menurut peneliti terdapat potensi dampak integrasi dalam konteks integrasi perekonomian dunia yang mampu mempengaruhi kondisi perekonomian suatu Negara. Sebagai gambaran contohnya saja perang dagang antara China dan Amerika berpotensi berdampak pada perekonomian di Indonesia.

\section{Pembahasan Hasil Penelitian dengan Penelitian Sebelumnya}

Hasil penelitian menunjukan bahwa hanya kurs dan SBI yang berpengaruh terhadap IHSG. Sementara STI dan KLSE tidak berpengaruh terhadap IHSG. Berikut perbandingan hasil penelitian dengan penelitian sebelumnya yang relevan.

\section{Tabel 10}

Perbandingan Hasil Penelitian dengan Penelitian Sebelumnya yang Relevan

\begin{tabular}{|c|c|c|c|}
\hline No. & Hasil Penelitian & \multicolumn{2}{|c|}{ Penelitian Sebelumnya yang Relevan } \\
\hline & & Konsisten & Tidak Konsisten \\
\hline 1. & $\begin{array}{l}\text { Kurs Berpengaruh Terhadaop } \\
\text { IHSG }\end{array}$ & $\begin{array}{ll}\text { - } & \text { Ni Made Sania } \\
\text { Candradewi dan Gerianta } \\
\text { Wirawan Yasa (2018). } \\
\text { - Dionysia Kowanda dkk } \\
\text { (2015). }\end{array}$ & $\begin{array}{l}\text { - Luh Gede Sri Artini } \\
\text { dkk (2017) }\end{array}$ \\
\hline 2. & $\begin{array}{l}\text { SBI Berpengaruh Terhadaop } \\
\text { IHSG }\end{array}$ & 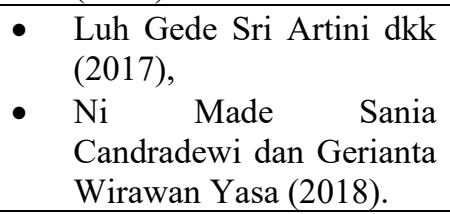 & $\begin{array}{ll}\text { - } & \text { Dionysia } \\
& \text { dkk (2015). }\end{array}$ \\
\hline 3. & $\begin{array}{lcc}\text { STI } & \text { Tidak } & \text { Berpengaruh } \\
\text { Terhadaop IHSG } & \end{array}$ & $\begin{array}{ll}\text { - } & \text { Ni Made Sania } \\
\text { Candradewi dan Gerianta } \\
\text { Wirawan Yasa (2018). }\end{array}$ & $\begin{array}{l}\text { - Luh Gede Sri Artini } \\
\text { dkk (2017) }\end{array}$ \\
\hline 4. & $\begin{array}{ll}\text { KLSE Tidak } & \text { Berpengaruh } \\
\text { Terhadaop IHSG } & \end{array}$ & - $\begin{array}{l}\text { R Safiroh Febrina dkk } \\
(2018)\end{array}$ & $\begin{array}{llr}\text { Ni Made } & \text { Sania } \\
\text { Candradewi } & \text { dan } \\
\text { Gerianta } & \text { Wirawan } \\
\text { Yasa (2018). } & \end{array}$ \\
\hline
\end{tabular}

\section{PENUTUP}

Berdasarkan hasil analisa dan pembahasan sebelumnya maka dapat disimpulkan bahwa ekonomi makro dalam hal ini menggunakan indikatpr kurs dan SBI mampu mempengaruhi IHSG. Sementara pasar modal Asia yang menggunakan STI dan KLSE tidak mampu mempengaruhi IHSG. 
Saran peneliti yang bisa diberikan berdasarkan penelitian ini adalah (1) bagi penelitian selanjutnya adalah menambah variabel makro ekonomi lainnya untuk memperkuat kondisi perekonomian pada saat periode penelitian karena dalam penelitian baru menggunakan dua indikator sebagai variabel makro ekonomi. (2) Bagi investor memang sebaiknya pertimbangan utama pada saat membuat keputusan investasi di pasar modal adalah dengan memperhatikan kondisi perekonomian secara makro pada saat itu dan bila menerapkan strategy follower maka pilihlah perilaku investor asing yang memiliki kondisi perekonomian secara makronya sama dengan kondisi di Indonesia pada saat yang sama.

\section{DAFTAR PUSTAKA}

Anghelache, Gabriela Victoria dan Andreea Negru Ciobanu. 2012. Correlation Stock Exchange Indices Under Both Normal and Financial Crisis Conditions. Theoretical and Applied Economics Volume XIX, No. 11(576), p 75-84.

Artini, Luh Gede Sri dkk. 2017. Analisis Fundamental Makro dan Integrasi Pasar Saham Dunia Dengan Bursa Efek Indonesia. Jurnal Manajemen, Strategi Bisnis dan Kewirausahaan, Vol.11, No.2,p 128-135.

Bodie, Kane, Marcus. 2014. Manajemen Portofolio dan Investasi, Edisi 9-Buku 2. Jakarta: Salemba Empat

Candradewi, Ni Made Sania dan Gerianta Wirawan Yasa. 2018. Pengaruh SBO, Kurs Rupiah, STI, SET dan KLSE pada Indeks Harga Saham Gabungan. E-Jurnal Akutansi Universitas Udayana, Vol.23, Jun, p 2359-2390

Christie , Maria Brenda, Khairunnisa dan Vaya Juliana Dillak. 2016. Pengaruh Variabel Makro Ekonomi di Pasar Saham : Bukti Dari Bursa Efek Indonesia (BEI) Periode 2006-2015. MODUS , Vol. 29 (2), p 219-232.

Febrina, R.Sarifoh, Sumiati dan Kusuma Ratnawati.Pengaruh Variabel Makro Ekonomi dan Harga Saham Asing Terhadap Indeks Harga Saham Gabungan. Jurnal Bisnis dan Manajemen Vol. 5 No.1, Januari 2018, p 118-126

Hapsari, Indah. 2017. Profitabilitas, Nilai Perusahaan, Pemoderasian Kualitas Audit: Perspektif Keagenan, Sinyal, Kualitas Audit (DeAngelo). JURNAL ASET (AKUNTANSI RISET), 9 (2), 2017, p 35-48.

Jogiyanto. 2010. Teori Portofolio dan Analisis Investasi, Edisi Ketujuh. Yogyakarta: BPFE.

Kilic, Yunus et.al. 2016. Asymmetric Information and Signaling Theory: Panel Causality Approach on the Relationship between Dividends and Earnings. Journal of Social Sciences, 15 (4), 1132-114.

Kowanda, Dionysia, Rowland Bismark Fernando Pasaribu dan Ahmad Fajri Shauti. 2015.Pengaruh Indeks Bursa Saham Asing dan Makro Ekonomi Terhadap Indeks Harga Saham Gabungan di Bursa Efek Indonesia Tahun 2010-2014. Jurnal Manajemen Indoensia, Vol.15, No.3.,p 225-234.

Robiyanto dan Rihfenti Ernayani.2018. Capital Market Integration In Some Asean Countries Revisited. Jurnal Manajemen, Volume XXII, No. 02, Juni, p 205-222.

Sihombing, Pardomuan dan Rizal. 2014. Pengaruh Indeks Saham Global dan Kondisi Makro Indonesia Terhadap Indeks Harga Saham Gabungan Bursa Efek Indonesia. Media Ekonomi Vol. 22 No. 2 Agustus, p 135-156

Sugiyono.2017.Metode Penelitian Manajemen. Bandung. Alfabeta

Tamisari, MarselaDwi. 2016. Stock Market Integration of Asean+6 on Indonesia Composite Stock Price Index (JKSEE). International Journal of Business and Management Invention, 5 (2), p 1-7.

Thao, TranPhuong dan Kevin Daly. 2012. The Impacts of the Global Financial Crisis on Southeast Asian Equity Markets Integration. International Journal of Trade, Economics and Finance, 3 (4), p 299-304.

Tjiptono Darmadji dan Hendy M. Fakhruddin. 2012. Pasar Modal Di Indonesia. Edisi Ketiga, Jakarta.: Salemba Empat. 
https://ekonomi.bisnis.com/read/20190511/9/921359/as-china-memanas-lagi-perdaganganRI-terancam

www.idx.co.id

finance.yahoo.com

www.bi.go.id

id.investing.com 